\title{
The Effects Of Individual Differences And Industry Stability On Auditors' Perceived Risk Assessments
}

Bilal A. Makkawi, (E-mail: bmakkawi@morgan.edu), Morgan State University Robert W. Rutledge, (E-mail: rr28@swt.edu), Southwest Texas State University

\begin{abstract}
The U. S. Public Oversight Board's Panel on Audit Effectiveness suggests that both audit effectiveness and efficiency may benefit from greater consideration being given to auditors' risk assessments. The association between several independent variables (e.g., tolerance-for-ambiguity, field dependence/independence, and industry stability) and auditors' perceived risk assessments is examined in an experimental setting. Six hypotheses suggested from a review of the literature are tested. The results indicate that industry stability and (to a lesser extent) tolerance-for-ambiguity (TFA) each have a main effect on auditors' perceived risk assessments. Further, these two variables are found to have a moderately significant interactive effect on such assessments. The level of industry stability (stable or unstable) is found to affect the risk assessments of low-TFA subjects more than high-TFA subjects. Implications of these results for the audit process are provided.
\end{abstract}

\section{Introduction}

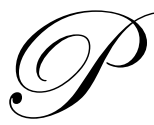

rofessional standards require auditors to assess the risk of material misstatements (audit risk at the financial statement level) as part of audit planning. Audit risk assessments are judgments that provide a basis for planning the nature, extent and timing of audit procedures (AICPA, 1997a, AU Section 312.01). Recently, audit research and professional standards have emphasized such assessments. In particular, much of the literature has focused on understanding various factors that influence the assessment of audit risk (e.g., audit fee pressure (Houston, 1999), belief revisions (Krishnamoorthy et al., 1999), and potentially fraudulent reports (Newman et al., 2001)).

The current environment for audit firms causes them to face rising costs and competition, an increasing volume of transactions by clients, and technological developments that affect both the client and audit firm. Given this changing environment, audit firms find it necessary to increase their focus on audit efficiency and effectiveness. Research into the area of audit risk assessment has important implications for these areas of audit efficiency and effectiveness (Dusenbury et al., 2000). Recently, the Panel on Audit Effectiveness stated that, "many audits [are] being conducted without sufficient consideration being given to the risk assessment process and that they consequently lack... in both effectiveness and efficiency." (Panel on Audit Effectiveness, 2000, p. 178).

The primary objective of this study is to examine audit risk assessments. Specifically, the study examines the effects of industry stability and cognitively-based individual differences (i.e., tolerance-for-ambiguity and field dependence/independence) on auditors' perceived risk assessments. The literature review that follows suggests potential main effects and several interactive effects of the independent variables on audit risk assessment.

The next section of the paper presents a discussion of relevant theoretical issues and the development of six testable hypotheses. The third section describes the experimental design, including the procedures used for the

Readers with comments or questions are encouraged to contact the authors via email. 
measurement of the variables. The data analysis and results of the experiment are presented in the fourth section. Lastly, the study concludes with a discussion of the results and significant implications for the audit process.

\section{Literature Review and Hypothesis Development}

Industry Stability

Audit risk is the risk of issuing an unqualified (clean) opinion when a qualified or adverse audit opinion is warranted. Prior research suggests that audit risk may be influenced by industry characteristics and/or a firm's operating environment (Corcell, 1989; Konrath, 1989; Harold, 1989; Peters, 1990; AICPA, 1993; Maletta \& Wright, 1996).

In a study conducted using a risk hypotheses generation model, Peters (1990) concluded that auditors evaluate inherent and control risks when generating risk hypotheses, and industry and firm's specific conditions are considered in audit program planning. Maletta and Wright (1996) found industry to affect error incidence, magnitude, and income. They found that regulated industries have a lower incidence of errors and a smaller percentage of routine errors (errors in systematically processed transactions) than unregulated industries. Additionally, they found that audit procedures based on internal versus external evidence detected more errors in the regulated than in the unregulated industries.

Professional pronouncements have also emphasized the importance of understanding the industry and the environment when planning an audit and evaluating the internal control of a client's accounting system. SAS 55 (AICPA 1990) (as amended by SAS 78, AICPA, 1995) states, "in making a judgment about the understanding of internal controls necessary to plan an audit, the auditor considers the knowledge obtained from other sources...other sources include an understanding of the industry in which an entity operates" (SAS 78, AICPA, 1995, paragraph 23). Specific industry conditions that the auditor should consider include competition, business failures, and the stability (i.e., nature and rate of change) within an industry (SAS 82, AICPA, 1997b).

According to contingency theory research, stability is a major factor in differentiating organizational environment (Child \& Manfield, 1972; Watson, 1975). Stability measures the extent and rate of change in an organization's environment. Greater uncertainty (and thus, greater audit risk) is associated with dynamic environments. Audit risk in a dynamic environment is higher, in part, due to greater discretion employees have in adapting to a changing environment, and due to greater difficulty in establishing standard operating procedures. These factors add to the risks facing an auditor (Kaplan, 1985). The above discussion suggests that industry stability is likely to affect the level of perceived audit risk. Hence, the first hypothesis is stated as follows:

H1: Perceived audit risk will be higher for an unstable industry than for a stable industry.

\section{Tolerance-for-Ambiguity}

The construct of tolerance-for-ambiguity (TFA) suggests that some individuals are indifferent to uncertainty and unstructured conditions (high TFA), while others are more sensitive to such conditions (low TFA). The effects of TFA on accounting, auditing, and other business decisions dates back to the 1970s (e.g., Dermer, 1973; Oliver \& Flamholtz, 1978). However, this construct receives a great amount of interest in the current literature.

Armstrong-Stassen (1998) examined the impact of downsizing on mangers in the Canadian Federal Government. She empirically tested the proposition by Feldman (1995) that survivors of downsizing who have a high TFA are likely to experience less difficulty in adjusting to the associated uncertainty. The findings of the study were that TFA did not significantly affect organizational commitment, morale or trust. However, high TFA managers had significantly favorable attitudes (job satisfaction and job security) and job performance and TFA was found to be predictor of the perceived risk of job loss. Judge, Thoresen, Pucik, and Welbournce (1999) examined managerial responses to organizational change. They examined data that was obtained from six organizations. The study reports a significant indirect relationship between TFA and the ability to cope with organizational change. Managers are likely to perceive 
organizational change as increased uncertainty and/or risk.

Pitt and Kannemeyer (2000) examined firm managers' adaptation of market strategies in successful start-up enterprises (i.e., an entrepreneur's willingness/ability to make appropriate adjustments in their marketing approach). They posit that there is a high degree of uncertainty (risk) associated with start-up enterprises, and that managers with a high TFA will be able to cope with this uncertainty. As predicted, TFA was found to be significantly positively associated with the level of success in adoption of marketing strategies. These findings suggest that high TFA managers are likely to be able to successfully accommodate risk and uncertainty.

The literature cited above suggests it is likely that TFA and risk perception are related. Auditors with a high TFA should perceive less audit risk than auditors with a low TFA. Hence, the second hypothesis is alternatively stated as follows:

H2: Perceived audit risk will be lower for auditors that have a high tolerance-for-ambiguity than for auditors that have a low TFA.

\section{Field Dependence/Independence}

Another factor that affects decision-making and risk perception is field dependence/-independence (FD/FI). Henderson and Nutt (1980) studied the effects of FD/FI on perception of risk. They found that cognitive style was a significant determinant factor in explaining risk perception and capital-project choice. Gul and Zaid (1981) tested the effect of FD/FI on accountants' confidence in making personnel layoff decisions. Results indicate that FD subjects were significantly more confident in their decisions than FI subjects. Gul (1987) found that FD/FI is an important variable that affects perceptions of auditor independence.

Some of the recent research on the effect of cognitive style of accountants on decision-making has been inconsistent. In a study of auditors' fraud detection, Pincus (1990) found FI auditors perform better than FD auditors, however Bernardi (1994) did not find such an effect. Mills (1996) found that FD/FI did not differ in the level of reliance that auditors placed on their clients' internal audit function. One possible reason for the different results can be attributed to a shift in FD/FI among auditors from 1984 to 1994. The Pincus (1990) study found accountants to be more FD than the norm, but Mills (1996) and Bernardi (1994) found accountants to be more FI than the norm.

The Group Embedded Figures Test (GEFT) is an instrument for measuring FD/FI. The GEFT measures the ability of an individual to isolate figures embedded into a bigger picture. The scores range from 0-18 with a national norm of 11-12. The median score on GEFT for the Pincus study was 12 while the median score on the Mills study and the Bernardi study was 14. Therefore, it is conceivable that by shifting the cutoff point from 12 to 14 (in order to maintain a median-cutoff point criterion) some accountants that would otherwise be classified as FI were classified as FD, which could have affected the results. As suggested by Smith (1999) and supported by the research of Gul and Zaid (1981), FD individuals have higher confidence levels in their decisions. This higher confidence may not allow the FD individuals to perceive the appropriate amount of risk in a given context. Therefore, the following alternatively stated hypothesis is suggested:

H3: Perceived audit risk will be lower for auditors that are field dependent (FD) than for auditors that are field independent (FI).

\section{Interactions between (Industry Stability and TFA) and (Industry Stability and FD/FI)}

As mentioned above, research supports the hypothesized effects of TFA and FD/FI on decision-making and audit risk perception. However some of the results were inconsistent. In an attempt to explain such inconsistencies, Kenrick and Dantchick (1983) advanced the idea of "interactionism." Within the interactionism framework, the effect of individual differences should not be studied in isolation, but rather, in relation to other variables. They concluded that the lack of consistent results is due to the lack of consideration of the confounding effect of other variables such as the 
nature of the task or the environment.

The interactionism framework is supported in the psychology and accounting literature. McGhee, Shields, and Birnberg (1978) found that the interaction of personality, task structure, and processor style explains a significant amount of the variation in information processing and decision-making. Blaylock (1981) investigated the components of risk perception. Subjects were provided with different decision-making scenarios within different environmental structures. The results indicate that varying the level of structure in an environment affects the level of perceived risk. Moreover, the interaction between the environment, cognitive style, and risk information available from the environment was significant in influencing the level of perceived risk. Gul (1986) found that bankers who scored low on the TFA scale were less confident in their decision about a company that received a qualified opinion (risky/ambiguous situation). No difference in confidence was found in the unqualified scenarios.

Another recent study suggests that TFA is likely to interact with the level of risk in the decision context. Ghosh and Ray (1997) conducted a laboratory experiment that examined the effects of tolerance-for-ambiguity and risk attitude on managerial decision choices. MBA student subjects assumed the role of consultant. The subjects determined sample sizes for quality inspections at four plants within a company. The results of the experiment indicate subjects with more tolerance-for-ambiguity chose smaller sample sizes, and had greater confidence in their decisions. This may be an indication that high TFA subjects perceive less risk which translates into a willingness to accept smaller sample sizes. Further the relationship between TFA and sample size/risk was found to interact with the level of risk characterized in the setting. Only when the setting was characterized by "low risk" was the relationship between TFA and sample size significant. Given these results, the following hypothesis is suggested:

H4a: The relationship between TFA and perceived audit risk will be influenced by the stability (risk) associated with the industry.

Gul and Zaid (1981) studied the effect of field dependence/independence (FD/FI) on accountant confidence. They found that FD accountants had a higher confidence level than FI accountants. In a later study, Gul (1990) asked bankers to estimate the stock price of two companies that differed only in the type of audit opinion report they received. The results indicated that FD subjects assigned a lower stock price than FI subjects. The difference in stock price estimation was significant only in the qualified opinion scenarios (risky/uncertainty). No significant difference was present in the unqualified opinion scenarios. In summary, the above studies tend to support the interactionism approach. Thus, the following hypothesis are suggested for the current study:

H4b: The relationship between FD/FI and perceived audit risk will be influenced by the stability (risk) associated with the industry.

\section{Interaction between Tolerance-for-Ambiguity and Field Dependence/Independence}

As supported in the discussion above, tolerance-for-ambiguity and field dependence/independence affect the perception of risk. However, personality (e.g., TFA) and cognitive style (e.g., FD/FI) are not always found to be independent. Prior research suggests a potential interactive effect on decision-making behavior (Blaylock, 1985). Gul (1984) tested the effect of tolerance-for-ambiguity and field dependence in moderating the relationship between accounting information and the degree of confidence with which managers make decisions. Although neither variable showed a significant main effect, there was a significant interaction between the two variables.

Further, Smith (1999) suggests a likely interaction effect between TFA and FD/FI on decision-making behavior and perception. He states, "confidence levels may be highest for field dependent individuals with a tolerance for ambiguity" (Smith, 1999, p. 20). If the interactive relationship between TFA and FD/FI has an effect on confidence levels, then it is reason to suspect that this relationship may also have an effect on the perception of audit risk. Thus, the following hypothesis is suggested:

H5: Tolerance-for-ambiguity and field dependence/independence will have a significant interactive effect on 
perceived audit risk.

\section{Research Methodology}

A laboratory study was conducted to investigate whether industry stability, tolerance-for-ambiguity, and/or field dependence/independence (as well as related interactions) had an effect on the perception of audit risk. A 2x2x2 experimental design is used to test the research hypotheses. The following model is proposed:

$Y_{i}=\beta_{1} X_{1 i}+\beta_{2} X_{2 i}+\beta_{3} X_{3 i}+\beta_{4} X_{1 i} X_{2 i}+\beta_{5} X_{1 i} X_{3 i}+\beta_{6} X_{2 i} X_{3 i}+\varepsilon$

Where:

$\mathrm{Y}=$ Perceived audit risk

$\mathrm{X}_{1}=$ Industry stability (IS)

$\mathrm{X}_{2}=$ Tolerance-for-ambiguity (TFA)

$\mathrm{X}_{3}=$ Field dependence/independence $(\mathrm{FD} / \mathrm{FI})$

$\varepsilon=$ Error term

The dependent variable $(\mathrm{Y})$ in the study is the subjects' perceived audit risk. The independent variables are industry stability $\left(\mathrm{X}_{1}\right)$, tolerance-for-ambiguity $\left(\mathrm{X}_{2}\right)$, and field dependence/ independence $\left(\mathrm{X}_{3}\right)$. The independent variable industry stability assumes two levels. The industry is classified as being either "stable" or "unstable." Cognitively-based variables are field dependence/independence and tolerance-for-ambiguity. Research indicates that the above variables individually or jointly affect risk perception, judgment, and decision- making. The Tolerance-for-Ambiguity (TFA) scale is used to measure tolerance-for-ambiguity, and the Group Embedded Figure Test (GEFT) scale is used to measure field dependence/independence.

\section{Experimental Task and Procedures}

The experiment requires subjects to indicate on a Likert-type scale their perceived audit risk. The experiment includes two versions of the instrument. The instrument represented a medium-size manufacturing company. The instrument contains an information set that describes the industry in which the firm operates, and current information about the industry and the economy. The two versions differ with respect to one variable, the stability of the industry in which the firm operates (see Appendix A). Industry stability is one element that affects the level of risk in an industry. A stable industry is represented by a manufacturing company in the tool industry. An unstable industry is represented by a manufacturing company in the computer industry.

Subjects included 103 senior accounting students who recently completed an undergraduate auditing class. The subjects were randomly divided into two groups, and each subject received both versions of the instrument. Subjects within group one received first information about industry "A" (the unstable industry) followed by information about industry "B" (the stable industry), and subjects within group two received the information in the reverse order. The subjects were asked to indicate on a Likert-type scale their perceived audit risk. Specifically, they were asked to indicate the level of risk at the financial statement level that they perceive is inherent in the industry. It is expected that the perceived audit risk should be higher in the unstable industry that in the stable industry (H1).

In addition to the financial information in the instruments, the subjects completed the Tolerance-for-Ambiguity Test (TFA) and the Group Embedded Figures Test (GEFT) (the instrument for measuring FD/FI). The GEFT instrument measures the ability of an individual to isolate figures embedded into a bigger picture. The scores range from 0-18 with a national norm of 11-12. Main effects were expected for TFA (H2), and for FD/FI (H3). As mentioned above, the effects of TFA and FD/FI on risk perception may not be conclusive due to the role of environment. In the current study an interaction effect is expected between industry risk (stability) and individual differences (field dependence/independence (H4a) and tolerance-for-ambiguity (H4b)). It is also likely that differences in perceived audit risk are a function of the interaction between TFA and FD/FI (H5). 


\section{Data Analysis and Results}

A three-way nested repeated measures design was used to examine the hypotheses of interest. The analysis includes the following three factors: (1) an "industry stability" factor with two levels (stable and unstable) where subjects evaluated perceived audit risk in each of two industries; (2) a nonrepeated tolerance-for-ambiguity (TFA) measure where subjects were classified as high TFA or low TFA; and (3) a nonrepeated FD/FI measure where subjects were classified as field dependent (FD) or field independent (FI). The dependent variable in the study is the subjects' perceived audit risk.

Industry Stability: The first hypothesis (H1) predicts that industry stability will have an effect on perceived audit risk. That is, perceived audit risk will be higher for an unstable industry than for a stable industry. The ANOVA results in Table 1, Panel B, reveals a significant main effect for industry stability $(\mathrm{F}=153.75 ; \mathrm{p}<0.001)$. Table 2 indicates that the average perceived risk is in the predicted direction. That is, subjects indicated that the stable industry has less perceived audit risk (38.30) than the unstable industry (72.33).

\begin{tabular}{|c|c|c|c|c|c|}
\hline \multicolumn{6}{|c|}{$\begin{array}{c}\text { Table 1 } \\
\text { Repeated Measures Analysis of Variance Tests of Hypotheses } \\
\text { for Between-and Within-Subjects Effects }\end{array}$} \\
\hline \multicolumn{6}{|c|}{ Panel A: Tests of Hypotheses for Between-Subjects Effects } \\
\hline Source & $\mathrm{DF}$ & Type III SS & Means Square & F-Value & $\operatorname{Pr}>\mathrm{F}$ \\
\hline TFA & 1 & 1039.92 & 1039.92 & 3.39 & 0.069 \\
\hline FD/FI & 1 & 35.93 & 35.93 & 0.12 & 0.733 \\
\hline TFA*FD/FI & 1 & 21.88 & 21.88 & 0.07 & 0.790 \\
\hline ERROR & 99 & 30386.64 & 306.94 & & \\
\hline \multicolumn{6}{|c|}{ Panel B: Tests of Hypotheses for Within-Subjects Effects } \\
\hline Source & DF & Type III SS & Means Square & F-Value & $\operatorname{Pr}>F$ \\
\hline STAB & 1 & 60272.59 & 60272.59 & 153.75 & 0.001 \\
\hline STAB*TFA & 1 & 1347.01 & 1347.01 & 3.44 & 0.067 \\
\hline STAB*FD/FI & 1 & 3.01 & 3.01 & 0.01 & 0.930 \\
\hline STAB*TFA*FD/FI & 1 & 362.58 & 362.58 & 0.92 & 0.339 \\
\hline ERROR & 99 & 38808.51 & 392.01 & & \\
\hline
\end{tabular}

Tolerance-for-Ambiguity: $\mathrm{H} 2$ predicts that tolerance-for-ambiguity (TFA) will affect perceived audit risk. The hypothesis suggests that perceived audit risk will be lower for auditors that have a high tolerance-for-ambiguity than for auditors that have a low TFA. The ANOVA results from Table 1, Panel A, indicate that the effect of TFA on perceived audit risk is marginally significant $(\mathrm{F}=3.39 ; \mathrm{p}>0.069)$. Table 3 indicates that the subjects' mean perceived audit risk is in the predicted direction (high TFA $=53.30$ and low TFA = 57.71). However, this result must be interpreted within the context of the predicted interaction effects that are discussed below.

Field Dependence/Independence: $\mathrm{H} 3$ predicts that perceived industry audit risk will be lower for auditors that are field dependent (FD) than for auditors that are field independent (FI). The results from the ANOVA in Table 1, Panel A, indicate that there was not a significant relationship between $\mathrm{FD} / \mathrm{FI}$ and perceived audit risk $(\mathrm{F}=0.12 ; \mathrm{p}<0.733)$. Table 3 shows that the average perceived audit risk for FD subjects is 55.00, and for FI subjects is 55.55.

Interactions (Industry Stability * TFA) and (Industry Stability * FD/FI): Hypotheses H4a and H4b suggest an interactive effect between: (a) industry stability and TFA on perceived audit risk, and (b) industry stability and FD/FI on perceived audit risk, respectively. 
Table 2

Mean Perceived Audit Risk Responses by Industry Stability for Tolerance-for-Ambiguity and Field Dependence/Independence (Including Standard Deviation and Cell Size)

Panel A: Mean Responses for Stable Industry

\begin{tabular}{|c|c|c|c|}
\hline & \multicolumn{2}{|c|}{ TFA Level } & \multirow[b]{2}{*}{$\underline{\text { Total }}$} \\
\hline & Low & High & \\
\hline \multicolumn{4}{|c|}{ FD/FI Level } \\
\hline \multirow[t]{3}{*}{$\underline{\underline{\text { FD }}}$} & 38.86 & 36.14 & 37.50 \\
\hline & $(13.44)$ & $(16.61)$ & $(15.00)$ \\
\hline & $\mathrm{n}=22$ & $\mathrm{n}=22$ & $n=44$ \\
\hline \multirow[t]{3}{*}{$\underline{\mathbf{F I}}$} & 36.60 & 40.59 & 38.90 \\
\hline & $(13.23)$ & $(22.52)$ & $(21.19)$ \\
\hline & $\mathrm{n}=25$ & $\mathrm{n}=34$ & $n-59$ \\
\hline \multirow[t]{3}{*}{ Total } & 37.66 & 38.84 & 38.30 \\
\hline & $(16.77)$ & $(20.36)$ & $(18.73)$ \\
\hline & $\mathrm{n}=47$ & $\mathrm{n}=56$ & $n=103$ \\
\hline \multicolumn{4}{|c|}{ Panel B: Mean Responses for Unstable Industry } \\
\hline & \multicolumn{2}{|c|}{ TFA Level } & \\
\hline & $\underline{\text { Low }}$ & High & $\underline{\text { Total }}$ \\
\hline \multicolumn{4}{|c|}{ FD/FI Level } \\
\hline \multirow[t]{3}{*}{ FD } & 76.36 & 68.64 & 72.50 \\
\hline & $(12.74)$ & (21.89) & (18.12) \\
\hline & $n=22$ & $n=22$ & $\mathrm{n}=44$ \\
\hline \multirow[t]{3}{*}{$\underline{\text { FI }}$} & 79.00 & 67.21 & 72.20 \\
\hline & (13.23) & (22.09) & (19.61) \\
\hline & $n=25$ & $n=34$ & $n-59$ \\
\hline Total & 77.77 & 67.77 & 72.33 \\
\hline
\end{tabular}

Table 3

Overall Mean Perceived Audit Risk Responses for Tolerance-for-Ambiguity and Field Dependence/Independence (Including Cell Size)

\section{TFA Level} $\underline{\text { Low }}$

FD/FI Level

$\underline{\text { FD }}$

$\underline{\text { FI }}$

$\underline{\text { Total }}$

Interaction (Tolerance-for-Ambiguity * Field Dependence/Independence): Hypothesis 5 predicts that tolerance-forambiguity and field dependence/independence will have a significant interactive effect on perceived audit risk. Table 1, Panel A, provides evidence that the interaction between TFA and FD/FI is not significant $(\mathrm{F}=0.07 ; \mathrm{p}<0.790)$. Further, examination of the means in Table 3 indicates that the effect of FD/FI on the perceived audit risk of low TFA subjects (57.61 vs. 57.80) is not different from the effect on high TFA subjects (52.39 vs. 53.90). Thus, the results do not support H5.
Examination of the ANOVA results in Table 1, Panel $\mathrm{B}$, indicates a significant interaction between industry stability and TFA $(\mathrm{F}=3.44 ; \mathrm{p}<0.067)$. The nature of the interaction can be determined by examination of the means in Table 2, Panel A. When the audit client is in a stable industry, the mean perceived audit risk is approximately the same for low TFA and high TFA subjects (37.66 vs. 38.84, respectively). However, when the audit client is in an unstable industry, the mean perceived audit risk differs between low TFA and high TFA subjects (Table 2, Panel B: 77.77 vs. 67.77, respectively). These results support Hypothesis 4a.

Table 1, Panel B does not indicate a significant interaction between industry stability and FD/FI $(\mathrm{F}=0.01 ; \mathrm{p}<0.930)$. Under stable industry conditions, the average perceived risk was 37.50 for FD subjects, and 38.90 for FI subjects (Table 2, Panel A). In the unstable industry, the average perceived risk was 72.50 for FD subjects, and 72.20 for FI subjects (Table 2, Panel B). It appears that field dependence/independence has about the same effect (insignificant) under both stable and unstable industry conditions. Thus, it appears that the relationship between FD/FI and perceived audit risk is not influenced by the industry stability, and $\mathrm{H} 4 \mathrm{~b}$ is not supported. 


\section{Discussion and Suggestions for Future Research}

This paper examined the effects of industry stability and cognitively-based individual differences (tolerance-forambiguity and field dependence/independence) on auditors' perceived risk assessments. Six research hypotheses were tested in a laboratory experiment using a $2 \times 2 \times 2$ experimental design (two levels each for industry stability, TFA, and FD/FI). Subjects were asked to indicate on the Likert-type scale the level of risk that they perceive at the financial statement level.

The first three hypotheses examine the main effects of the three independent variables on perceived risk assessments. Industry stability (H1) and TFA (H2) were each found to have a significant main effect on such assessments. As hypothesized, perceived audit risk assessments were higher for an unstable industry (as compared to a stable industry), and for low TFA subjects (as compared to high TFA subjects). FD/FI was not found to have a significant effect the perceived audit risk of subjects. The interpretation of main effects is not entirely reliable without first examining potential higher order interactions.

Hypotheses $4 \mathrm{a}$ and $4 \mathrm{~b}$ suggest that perceived audit risk will be influenced by an interactive relationship between: (a) industry stability and TFA, and (b) industry stability and FD/FI. The results support a significant interaction effect between industry stability and TFA on perceived audit risk. Specifically, subjects' TFA did not influence perceived audit risk assessments in the context of a stable industry. However, in the context of an unstable industry, perceived audit risk was influenced by subjects' TFA. Low TFA subjects perceived higher audit risk than high TFA subjects only in an unstable industry environment. Thus, it is not sufficient to evaluate the effects of industry stability or TFA in isolation of one another. The effect of one of these variables on audit risk assessment is dependent upon the level of the other. The results did not find such an interaction effect between industry stability and FD/FI.

Lastly, Hypothesis 5 suggests an interactive effect between tolerance-for-ambiguity and field dependence/independence on perceived audit risk. However, the results of the experiment did not support such an interactive relationship between these two variables on audit risk assessments.

\section{Suggestions for Future Research}

The overall judgment of risk at the financial-statement level affects the overall planning of the audit. Audit risk affects the experience and training requirements of assigned personnel because different audit risk necessitates staff with different experience levels. Various risk levels cause the auditor to alter the extent, nature, and timing of auditing procedures throughout the auditing engagement. The auditor should also consider the audit risk at the individual account level because this will affect the extent and scope of auditing procedures applied to that account.

The current study has important implications for the overall audit process. It increases the understanding of the role of industry stability and individual differences in audit judgment. The perception of greater risk by low TFA auditors may cause them to behave in a more cautious manner and result in a tendency to "over audit." Over auditing is the application of auditing procedures that are not warranted based on the existing audit risk (i.e., an inefficient use of resources). For example, an overly cautious auditor might perceive internal control to be highly unreliable, and thus, expend more resources than needed on substantive testing. Understanding the effects of TFA may improve the audit through more efficient resource allocation (e.g., such as staff assignment), and through an increase in effectiveness of the audit process. Further research into the effects of TFA should be considered.

Additionally, understanding factors that influence perceived audit risk (e.g., individual differences, and industry stability) may affect the amount of audit procedures that are performed (audit efficiency) and the quality of the audit (audit effectiveness). Future research should into the factors that influence perceived audit risk may result in more consistent decisions and lead to a reduction in the risk of lawsuits. Most importantly, the study suggests that it is not sufficient to study the effect of various factors on audit risk assessment in isolation from one another. For example, the results found that it is not possible to predict the effects of TFA on audit risk assessments without knowing additional information about the context of the decision (specifically, the level of industry stability). 
In summary, this study extends previous research by examining the effect of industry characteristics (stability), and cognitively-based individual differences (e.g., field dependence/independence, and tolerance-for-ambiguity), and the interrelationships between these variables on perceived audit risk.

\section{References}

1. American Institute of Certified Public Accountants. (1990), Statement on Auditing Standards No 55: Consideration of the Internal Control Structure in a Financial Statement Audit. New York: AICPA.

2. American Institute of Certified Public Accountants. (1993), Audit Risk Alert. New York: AICPA

3. American Institute of Certified Public Accountants. (1995), Statement on Auditing Standards No 78: Consideration of Internal Control in a Financial Statement Audit. New York: AICPA.

4. American Institute of Certified Public Accountants (AICPA). (1997a), Codification of Statements on Auditing Standards (Including Statements on Standards for Attestation Engagements), Numbers 1 to 82, New York, NY: AICPA.

5. $\quad$ American Institute of Certified Public Accountants. (1997b), Statement on Auditing Standards No 82: Consideration of Fraud in a Financial Statement Audit. New York: AICPA.

6. Armstorng-Stassen, M. (1998), "Downsizing the Federal Government: A Longitudinal Study of Managers' Reactions", Canadian Journals of Administrative Sciences, Vol. 15, No. 4, pp. 310-321.

7. Bernardi, R. (1994), "Fraud Detection: The Effect of Client Integrity and Competence and Auditor Cognitive Style", Auditing: A Journal of Practice \& Theory, Vol. 13 (Supplement), pp. 68-84.

8. $\quad$ Blaylock, B. K. (1981), "Methods for Studying Perception of Risk", Psychological Reports, 49, pp. 899-902.

9. Blaylock, B. K. (1985), "Risk Perception: Evidence of an Interactive Process", Journal of Business Research, (June), pp. 207-221.

10. Child, J., and R. Mansfield. (1972), “Technology, Size and Organization Structure”, Sociology, Vol. 6, pp. 369393.

11. Corcell, F. (1989), "How to Identify a 'Sick' Company in Time to Help It", Practical Accountant, Vol. 14, (October), pp. 90-99.

12. Dermer, J. (1973), "Cognitive Characteristics and the Perceived Importance of Information", The Accounting Review, Vol. 48, No. 3, pp. 511-519.

13. Dusenbury, R. B., J. L. Reimers, and S. W. Wheeler. (2000), "The Audit Risk Model: An Empirical Test for Conditional Dependencies among Assessed Component Risks", Auditing: A Journal of Theory \& Practice, Vol. 19, No. 2, pp. 105-118.

14. Feldman, D.C. (1995), "The impact of downsizing on Organizational Career Development Activities and Employee Career Development Opportunities", Human Resource Management Review, Vol. 5, pp. 189-221.

15. Ghosh, D, and M. R. Ray. (1997), "Risk, Ambiguity and Decision Choice: Some Additional Evidence", Decision Sciences, Vol. 28, No. 1, pp. 81-104.

16. Gul, F. A., and O. Zaid. (1981), "Field Dependence and Accountants' Confidence in Decisions", Psychological Reports, Vol. 49, No. 3, pp. 949-950.

17. Gul, F. A. (1984), "The Joint and Moderating Role of Personality and Cognitive Style on Decision Making", The Accounting Review, Vol. 59, No. 2, pp. 264-277.

18. Gul, F. A. (1986), "Tolerance for Ambiguity, Auditors' Opinions and Their Effects on Decision Making”, Accounting \& Business Research, (spring), pp. 99-105.

19. Gul, F. A. (1987), "Cognitive Style as a Moderating Factor in Subjects' Perceptions of Auditor Independence", Accounting and Finance, Vol. 27, No. 1, pp. 37-48.

20. Gul, F. A. (1990), "Qualified Audit Reports, Field Dependence Cognitive Style, and Their Effects on Decision Making", Accounting \& Finance, Vol. 30, No. 2, pp. 15-27.

21. Harold, R. G. (1989), "Development of a Risk Model: A Project Approach”, Internal Auditor, Vol. 46, No. 6, pp. 51-57.

22. Henderson, J., and P. Nutt. (1980), "The Influence of Decision Style on Decision Making Behavior", Management Science, Vol. 26, No. 4, pp. 371-386.

23. Houston, R. W. (1999), "The Effect of Fee Pressure and Client Risk on Audit Seniors' Time Budget Decisions", Auditing: A Journal of Theory \& Practice, Vol. 18, No. 2, pp. 70-86. 
24. Judge, T. A., C. J. Thoresen, V. Pucik, and T. M. Welbournce. (1999), "Managerial Coping with Organizational Change: A Dispositional Perspective”, Journal of Applied Psychology, Vol. 84, No. 1, pp. 107-122.

25. Kaplan, S. (1985), "An Examination of the Effects of Environmental and Explicit Internal Control Evaluation on Planned Audit Hours", Auditing: A Journal of Practice and Theory, Vol. 5, No. 1, pp. 12-25.

26. Kenrick, B. T., and A. Dantchick. (1983), "Interactionism, Idiographics and the Sociopsychological Innovation of Personality", Journal of Personality, Vol., 51, No. 3, pp.286-307.

27. Konrath, L. F. (1989), "Classification of Audit Risk Factors for Planning and Program", The Ohio CPA Journal, Vol. 48, No. 4, pp. 6-12.

28. Krishnamoorth, G., T. J. Mock, and M. T. Washington. (1999), "A Comparative Evaluation of Belief Revision Models in Auditing", Auditing: A Journal of Theory \& Practice, Vol. 18, No. 2, pp. 105-127.

29. Maletta M., and A. Wright. (1996), "Audit Evidence: An Examination of Industry Error Characteristics", Auditing: A Journal of Practice and Theory. Vol. 15, No. 1, pp. 71-87.

30. McGhee, W., M. D. Shields, and J. Birnberg. (1978), “The Effect of Personality on Subject's Information Processing”, The Accounting Review, Vol. 53, No. 3, pp. 681-697.

31. Mills, T. Y. (1996), “The Effect of Cognitive Style on External Auditors' Reliance Decisions on Internal Audit Functions", Behavioral Research in Accounting, Vol. 8, pp. 49-73.

32. Newman, D. P., E. Patterson, and R. Smith. (2001), "The Influence of Potentially Fraudulent Reports on Audit Risk Assessment and Planning", The Accounting Review, Vol. 76, No. 1, pp. 59-80.

33. Oliver, J., and E. Flamholtz. (1978), "Human Resource Replacement Cost Numbers, Cognitive Information Processing and Personnel Decisions: A Laboratory Experiment", Journal of Business, Finance and Accounting, (summer), pp. 137-157.

34. Panel on Audit Effectiveness. (2000), The Panel on Audit Effectiveness Report and Recommendations, August 31, 2000, Stamford, CT: The Public Oversight Board.

35. Peters, J. (1990), “A Cognitive Computational Model of Risk Hypothesis Generation”, Journal of Accounting Research, Vol. 28(supplement), pp. 83-109.

36. Pincus, K. V. (1990), "Auditor Individual Differences and Fairness of Presentation Judgments", Auditing: A Journal of Practice \& Theory, Vol. 9, No. 3, pp. 150-166.

37. Pitt, L.F. and R. Kannemeyer. (2000), "The Role of Adaptation in Microenterprise Development: A Marketing Perspective", Journal of Developmental Entrepreneurship, Vol. 5, No. 2, pp. 137-155.

38. Smith, M. (1999), "Gender, Cognitive Style, Personality and Management Decision-Making", Management Accounting, Vol. 77, No. 7, pp. 18-22.

39. Watson, D. (1975), "The Structure of Project Teams facing Differentiated Environments: an Exploratory Study in Public Accounting Firms", The Accounting Review, Vol. 50, No. 2, pp. 259-273.

\section{Appendix A: Cases Used in the Experiment}

\section{Stable Industry}

1. Your firm is currently engaged in the audit of a client, Tool Time, Inc., a calendar year medium sized manufacturer of machine tools that shape metal parts to size and contour them by cutting away the unwanted parts. Machine tools type include 1) Turning such as automatic bar machines 2) Boring which cuts cylindrically into metal, 3) planning and shaping and 4) drilling and grinding.

2. The machine tool industry showed strong performance in the last year. Most of the performance is attributable to the U.S. economy as a whole, including higher capital spending, rising capacity utilization rates and strong growth in real Gross Domestic Product (GDP). Another reason for the strong performance is the strong demand from the U.S. automobile industry, which had a very strong increase in production. The automobile industry accounts for about $30 \%$ of total machines tool industry orders in an average year.

3. Profitability of the machine tool industry has been rising. The increased demand coupled with a decrease in global production especially in Japan and Germany led to a reduction in competition and allowed for more price increases and higher gross margins. 
4. The increase in sales is due in part to the need for continuous modernization of the U.S. industrial base. According to the U.S. Commerce Department the average age of metal working machinery was 10 years in 1998 which is a 54-year high. The aging of the industrial base resulted in an increase in replacement demand for machine tools.

5. The outlook for the next few years continues to be favorable. The machine tool industry will benefit from 1) the anticipated reasonable growth in the GDP (about 3\%), 2) increase in factory capacity utilization rate, 3) continuous rise in spending for producers' durable equipment, and 4) The development of new vehicle models and government-mandated mileage and emissions standards.

6. It should be noted that the increase in factory capacity utilization has not caught up with increase in demand, hence production is falling behind sales, and inventory levels are now below average. Moreover the machine tool industry is considered in general to be a very stable industry (e.g., a low rate of entry and exit).

7. You are the senior on the job. Based on the above information, indicate on the scale below the level of risk at the financial statement level that you perceive is inherent in this industry:

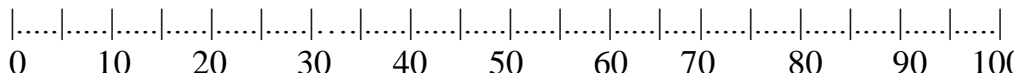

$$
\text { Least risk } \quad \text { Maximum risk }
$$

\section{Unstable Industry}

1. Your firm is currently engaged in the audit of a client, Chips World, Inc., a calendar year medium sized manufacturer of microprocessors for the personal computer. Chips World manufactures generic chips that compete with Intel 586 Pentium microprocessors.

2. The generic microprocessor industry is very price sensitive. The gross margin is as low as $8 \%$. Hence a minor change in price has a dramatic affect on the profitability of the producing firms, especially those with high fixed overhead costs. As with all technology products, the advent of a more advanced product has a severe effect on the selling price of preexisting inventory of the older models. The introduction by Intel of their MX Pentium Chip put more price pressure on companies like Chip World that has a large inventory of the 586 chips that would be considered to be technologically obsolete, and thus command a much lower market value.

3. The computer industry is considered to be a very unstable industry (e.g., a high rate of entry and exit). It is also a cyclical industry that is directly affected by the business or economic cycle. The slow down in economic activity (a 2.4\% growth in GDP in 1999) affects the demand for durable goods such as computers, and that in turn affects the demand for microprocessors, thus putting more price pressure.

4. You are the senior on the job. Based on the above information, indicate on the scale below the level of risk at the financial statement level that you perceive is inherent in this industry:

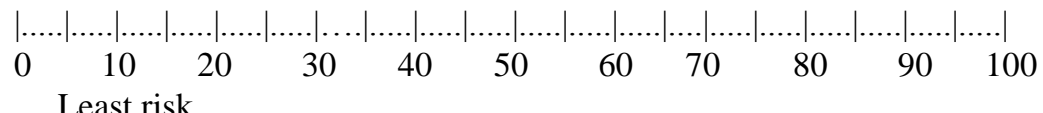

Least risk

Maximum risk 
Notes 